\title{
Studies on the intracerebral injection of bleomycin free and entrapped within liposomes in the rat
}

\author{
G FIRTH, ${ }^{*}$ AS OLIVER, $\dagger$ RO MCKERAN ${ }^{*} \dagger \ddagger$
}

From the Department of Biochemistry, St George's Hospital Medical School, London, $\dagger$ Hurstwood Park Neurological Centre, Sussex, ${ }^{*}$ and the Neurology Department, Atkinson Morley’s Hospital $\ddagger$ London, UK

SUMMARY Reverse phase prepared liposomes of defined composition (dipalmitoyl phosphatidyl choline, cholesterol and dipalmitoyl phosphatidic acid; 7:2:1; DPC) when injected intracerebrally in the rat produced no tissue damage beyond that of the penetrating wound, or altered behaviour pattern over 1 week of observation. The cerebral tissue response and behaviour of rats injected with bleomycin of increasing concentration, free and entrapped within liposomes was studied in short and long term experiments. In separate experiments blood, urine and tissue levels of bleomycin were measured after intracerebral injection of free and liposome entrapped bleomycin in the rat. These studies demonstrated that bleomycin when entrapped within liposomes and injected intracerebrally was of low toxicity to normal cerebral tissue, and was cleared more slowly from the injection site than when the free drug was injected. The results obtained indicated a potential application for drugs entrapped within liposomes acting as a depot preparation in the treatment of cerebral gliomas.

It has been calculated that to achieve an adequate concentration of a drug for a therapeutically significant period of time in the central core of a 6 $\mathrm{cm}$ diameter glioblastoma multiforme at a depth of $1-3 \mathrm{~cm}$ from the perfused rim, a plasma level would have to be maintained at therapeutic concentrations for 10-24 hours.' This is difficult to achieve clinically which perhaps goes some way to explaining the disappointing results of chemotherapy in the treatment of human cerebral gliomas. Cerebral gliomas are unique in one particular respect in that in no other tumour is there such a clear kinetic difference between the neoplastic and the normal tissue. The limited effectiveness of certain cell cycle specific drugs such as bleomycin in the treatment of human cerebral gliomas might be due therefore in part to the difficulty in maintaining adequate therapeutic concentrations of drug at the tumour site, rather than an inate ineffectiveness of the drug. Bleomycin has been found to be very effective in the treatment of human ectodermally derived tumours ${ }^{2}$ and animal

Address for reprint requests: Dr RO McKeran, Department of Neurology, Atkinson Morley's Hospital, 31 Copse Hill, Wimbledon, SW20 0NE, UK

Received 9 August 1983 and in revised form 19 December 1983. Accepted 22 December 1983 gliomas. ${ }^{3}$ Bleomycin does not normally cross the blood brain barrier but some passage does occur in and around cerebral gliomas because of the breakdown in the normal blood brain barrier. ${ }^{4}$ Intracerebral injections of bleomycin in glioma bearing animals was found to be more effective than when given intravenously. ${ }^{5}$ Animal studies have suggested that it might be necessary to give large doses of bleomycin with inevitable toxic side effects in order to obtain significant regression of glioma tissue when given by routine systemic administration. ${ }^{4}$ We have recently demonstrated the possibility of using certain cell-cycle specific drugs entrapped within reverse phase prepared liposomes acting as a depot preparation to achieve sustained release of drug at therapeutic concentrations in vitro. ${ }^{6}$ It has been suggested that bleomycin may be taken up specifically by glioma tissue as compared to normal tissue which might be advantageous if the drug were administered locally. ${ }^{4}$ We have therefore continued our investigations of the potential use of drugs entrapped within liposomes in the treatment of cerebral gliomas by assessing the cerebral toxicity of liposomes and also of free and entrapped bleomycin within liposomes after intracerebral injection in the rat with subsequent measurement of blood, urine and tissue level of bleomycin. 


\section{Materials and methods}

\section{Materials}

Cholesterol (C), dipalmitoyl phosphatidyl choline (D) and dipalmitoyl phosphatidic acid (P) of highest obtainable purity were purchased for Sigma Chemical Company. Bleomycin was kindly donated by Lundbeck Ltd. Sepharose 6B was obtained from Pharmacia Ltd. Bleomycin antisera and donkey antisheep serum were obtained from Guildhay, University of Surrey. 125I was obtained from Amersham International. All other reagents were obtained through BDH Ltd.

Iodination of bleomycin was performed using the method of Salacinski et al..$^{7}$ Bleomycin $(5 \mu \mathrm{g})$ in $10 \mu \mathrm{l}$ of $0.2 \mathrm{M} / \mathrm{l} \mathrm{pH}$ 7.4 phosphate buffer was iodinated with $0.5 \mathrm{mCi}$ of $\mathrm{Na}$ 125I. Separation was achieved using Sephadex G10.

Preparation of liposomes was by the reverse phase method described by Szoka and Papahadjopaulos. ${ }^{8}$

Cerebral toxicity studies Reverse phase prepared liposomes were made containing $66 \mu$ moles of lipid incorporating either $0.02 \mathrm{M}$ sodium phosphate buffer $\mathrm{pH} 6.0$ or 7.5 $\mathrm{mg}$ of bleomycin with $125 \mathrm{I}$ bleomycin in the same buffer. Suitable dilutions were made and $5 \mu$ l aliquots were injected intracerebrally in subsequent experiments.

Male Wistar rats weighing approximately $250 \mathrm{~g}$ were anaesthetised using an air/nitrous oxide/halothane mixture. A $1 \mathrm{~mm}$ diameter hole was drilled through the skull 2.7 mm anterior to the bregma point and $1.5 \mathrm{~mm}$ laterally over the left hemisphere using a stereotactic manipulator. Suitable dilutions in a total volume of $5 \mu \mathrm{l}$ of free liposome and of free and liposome-entrapped bleomycin were injected at a depth of $2 \mathrm{~mm}$ in the cerebral hemisphere cortex using a Hamilton syringe and the stereotactic manipulator. Two animals were studied at each concentration of lipid and of bleomycin, free or when entrapped within liposomes with two buffer only controls. The rats were allowed to recover in metabolic cages where food consumption, urine and faeces production and general behaviour were observed for 7 days. The animals were then sacrificed and the brain removed after it had been perfused with heparinised saline followed by buffered formal saline. The brains were stored in buffered formal saline at $4^{\circ} \mathrm{C}$ until processed for histology. Serial sections were cut and stained with haematoxylin and eosin. The serial sections were coded and the degree of cerebral damage was assessed by two observers with light microscopy who had no knowledge of the code. The degree of histological damage was graded on a 3 point scale (table 1).

Tissue distribution studies of bleomycin after intracerebral injection free and entrapped within liposomes

Male Wistar rats anaesthetised with pentabarbitone were injected intracerebrally with either free bleomycin or bleomycin entrapped within liposomes by the technique described above. Repeated blood and urine samples were obtained over a period of 4 hours and assayed for bleomycin. The animals were sacrificed at 4 hours, and tissue samples were taken and stored at $-20^{\circ} \mathrm{C}$ until assayed for bleomycin. Additional similar longer term experiments were performed after intracerebral injection of free bleomycin and bleomycin entrapped within liposomes in rats anaesthetised with an air/nitrous oxide/halothane mixture. These animals were sacrificed at 24 and 76 hours and 7 days, with blood, urine and tissue samples obtained at those times.

Assay of bleomycin Radioimmunoassay of bleomycin was performed according to the following protocol. Specimens of serum, urine, or standards $(20 \mu \mathrm{l})$ were diluted in $125 \mathrm{I}$ bleomycin $(200 \mu \mathrm{l}, 30,000 \mathrm{cpm})$ in phosphate buffer $(0.05 \mathrm{M}, \mathrm{pH} 7.4)$. Bleomycin antisera $(200 \mu \mathrm{l})$ in the same buffer was then added at a dilution to give $50 \%$ binding of the radioactive label. Following an overnight incubation at room temperature donkey anti-sheep serum $(200 \mu \mathrm{l}$ of a $1: 20$ dilution in the same phosphate buffer) was added followed by $12 \%$ polyethylene glycol $(200 \mu \mathrm{l})$. The assay tubes were then centrifuged for 10 minutes at $2000 \mathrm{~g}$, the supernatants removed by suction and radioactivity of the pellets counted for 30 seconds in a Wilj gamma counter. The reproducibility of the method was found to have an interassay coefficient of variation (CV) of $3.5 \%$ at a level of $50 \mathrm{ng} / \mathrm{l}$ and an intraassay $\mathrm{CV}$ of $7 \cdot 5 \%$ at a level of 50 $\mathrm{ng} / \mathrm{l}$. Where concentrations of drug in specimens was in

Table 1 Cerebral histological appearance after intracerebral injection of liposomes and bleomycin free or entrapped within liposomes

\begin{tabular}{|c|c|c|c|}
\hline Liposome lipid content ( $\mu$ moles) & Drug content ( $\mu g$ ) & Histological appearance & Behavioural response \\
\hline $\begin{array}{l}0.33 \\
0.165 \\
0.066 \\
0.033 \\
0.0033\end{array}$ & $\begin{array}{l}\text { Nil } \\
\text { Nil } \\
\text { Nil } \\
\text { Nil } \\
\text { Nil }\end{array}$ & $\begin{array}{c}\text { Needle tract only } \\
\text { ", } \\
",\end{array}$ & $\begin{array}{c}\text { No change detected } \\
" \\
"\end{array}$ \\
\hline $\begin{array}{l}0.33 \\
0.083 \\
0.0083 \\
0.00083 \\
0.000083\end{array}$ & $\begin{array}{c}400 \\
100 \\
10 \\
1 \\
0.1\end{array}$ & $\begin{array}{l}++\quad+ \\
\pm \quad+ \\
+\quad++ \\
\pm \quad+ \\
\text { Needle tract only }\end{array}$ & $\begin{array}{c}\text { No change detected } \\
, " \\
" \\
"\end{array}$ \\
\hline \multirow[t]{2}{*}{$\begin{array}{l}\text { Nil } \\
\text { Nil }\end{array}$} & $\begin{array}{r}400 \\
10\end{array}$ & $\begin{array}{c}\text { Needle tract only } \\
"\end{array}$ & $\begin{array}{c}\text { No change detected } \\
"\end{array}$ \\
\hline & Buffer only & No change & No change \\
\hline
\end{tabular}

$\pm=$ Minimal local reaction around needle tract.

$+=$ Local reaction around needle tract.

$++=$ Marked local reaction around needle tract. No necrosis. 
excess of the highest standard used in the assay the specimens were reassayed at appropriate dilutions.

Tissue samples were homogenised using a teflon and glass homogeniser in 10-15 times their own volume of 0.05 $\mathrm{M}$ phosphate buffer $\mathrm{pH} 7 \cdot 4$ containing $1 \mathrm{~g} / \mathrm{l}$ gelatine, and shaken with an equal volume of chloroform. Samples were centrifuged for 10 minutes at $1000 \mathrm{~g}$ and the clear supernatants asayed as above. Normal rat serum $(20 \mu \mathrm{l})$ was added to both sample and standard tubes in order to minimise non specific protein effects.

\section{Results}

\section{CEREBRAL TOXICITY STUDIES}

No alteration of behaviour, food consumption, urine or faceal production was detected in any of the animals after intracerebral injection of reverse phase prepared liposomes containing either buffer or bleomycin over a period of 1 week's observation except in the case of one animal which was subsequently shown to have developed a cerebral abscess. No animals were seen to have a seizure or develop a hemiparesis.
The cerebral histological changes observed after intracerebral injection of free bleomycin or reverse phase prepared liposomes containing either buffer or bleomycin are shown in table 1 . No histological change was observed in the cerebral hemispheres after injection of different amounts of reverse phase prepared liposomes or free bleomycin. A mild local inflammatory response was recorded when bleomycin was entrapped within liposomes tending to be more marked at the higher concentrations.

\section{TISSUE DISTRIBUTION STUDIES OF BLEOMYCIN AFTER INTRACEREBRAL INJECTION, FREE AND ENTRAPPED WITHIN LIPOSOMES}

The blood and urine levels of bleomycin in the short (4 hours) and longer term experiments (1, 3 and 7 days) obtained after intracerebral injection of free and liposome entrapped bleomycin are shown in table 2 ( $a$ and b) and graphically in fig 1 . Bleomycin appeared rapidly in the blood and urine after intracerebral injection of the free drug whereas when entrapped within liposomes drug levels in the

Table 2 (a) Intracerebral injection of free bleomycin and bleomycin entrapped within liposomes in the rat-short term experiment

\begin{tabular}{|c|c|c|c|c|c|c|c|c|}
\hline & \multirow{2}{*}{$\begin{array}{l}\text { Dose injected } \\
\mu g\end{array}$} & \multicolumn{2}{|l|}{ Blood } & \multicolumn{3}{|l|}{ Urine } & \multicolumn{2}{|c|}{ Total remaining in brain } \\
\hline & & $\underset{\text { (mins) }}{\text { Initial } T 1 / 2}$ & $\begin{array}{l}\text { Peak level } \\
\text { ng/ml }\end{array}$ & $\begin{array}{l}\text { Peak level } \\
\mu g / m l\end{array}$ & $\begin{array}{l}\text { Total output in } \\
4 \mathrm{hrs}(\mu \mathrm{g})\end{array}$ & $\begin{array}{l}\% \text { total dose } \\
\text { excreted in } 4 \\
\text { hours }\end{array}$ & $\mu g$ & $\%$ \\
\hline A. Free & $\begin{array}{r}19 \cdot 3 \\
19 \cdot 3 \\
4 \cdot 6 \\
5 \cdot 2\end{array}$ & $\begin{array}{l}19 \cdot 0 \\
32 \cdot 0 \\
33 \cdot 0 \\
47 \cdot 0\end{array}$ & $\begin{array}{r}177 \cdot 6 \\
125 \cdot 7 \\
25 \cdot 6 \\
14 \cdot 1\end{array}$ & $\begin{array}{r}24 \cdot 9 \\
72 \cdot 8 \\
20 \cdot 3 \\
5 \cdot 4\end{array}$ & $\begin{array}{r}9 \cdot 36 \\
12 \cdot 07 \\
3 \cdot 12 \\
2 \cdot 32\end{array}$ & $\begin{array}{l}48 \cdot 5 \\
62 \cdot 5 \\
68 \cdot 0 \\
44 \cdot 6\end{array}$ & $\begin{array}{l}0.51 \\
3.91 \\
0.77 \\
0.88\end{array}$ & $\begin{array}{r}2.6 \\
20.3 \\
16.7 \\
16.9\end{array}$ \\
\hline \multirow[t]{2}{*}{$\begin{array}{l}\text { B. liposome } \\
\text { entrapped }\end{array}$} & $7 \cdot 6$ & & $2 \cdot 3$ & 0.55 & \multirow{2}{*}{$\begin{array}{c}0.047 \\
(40 \text { mins }) \\
0.646 \\
0.160\end{array}$} & \multirow{2}{*}{$\begin{array}{l}0.6 \\
(40 \text { mins }) \\
8.5 \\
2.4\end{array}$} & \multirow{2}{*}{$\begin{array}{l}5 \cdot 79 \\
(40 \text { mins }) \\
2 \cdot 67 \\
3 \cdot 29\end{array}$} & $76 \cdot 2$ \\
\hline & $\begin{array}{l}7 \cdot 6 \\
6 \cdot 7\end{array}$ & - & $\begin{array}{l}2 \cdot 3 \\
2 \cdot 7\end{array}$ & $\begin{array}{l}1.46 \\
0.45\end{array}$ & & & & $\begin{array}{l}35 \cdot 1 \\
49 \cdot 1\end{array}$ \\
\hline
\end{tabular}

(b) Intracerebral injection of free bleomycin and bleomycin entrapped within liposomes in the rat-long term experiment

\begin{tabular}{|c|c|c|c|c|c|c|}
\hline & \multirow[t]{2}{*}{ Dose injected ( $\mu g$ ) } & \multirow[t]{2}{*}{ Time of sampling } & \multirow{2}{*}{$\begin{array}{l}\text { Serum bleomycin } \\
\text { ng/ml }\end{array}$} & \multirow{2}{*}{$\begin{array}{l}\text { Urine bleomycin } \\
\text { ng/ml }\end{array}$} & \multicolumn{2}{|c|}{ Total remaining in brain } \\
\hline & & & & & $\mu g$ per brain & $\begin{array}{l}\% \text { of total amount } \\
\text { injected }\end{array}$ \\
\hline A. Free & $\begin{array}{l}9 \\
9 \\
9\end{array}$ & $\begin{array}{l}24 \mathrm{~h} \\
72 \mathrm{~h} \\
7 \text { days }\end{array}$ & $\begin{array}{l}2.4 \\
2.7 \\
\text { ND } \\
\text { ND } \\
\text { ND } \\
\text { ND }\end{array}$ & $\begin{array}{l}11 \cdot 5 \\
\text { NA } \\
\text { ND } \\
\text { ND } \\
\text { ND } \\
\text { ND }\end{array}$ & $\begin{array}{c}0.08 \\
0.12 \\
<0.016 \\
0.029 \\
0.015 \\
0.014\end{array}$ & $\begin{array}{c}0.9 \\
1.3 \\
<0.2 \\
0.3 \\
0.17 \\
0.16\end{array}$ \\
\hline $\begin{array}{l}\text { B. liposome } \\
\text { entrapped }\end{array}$ & $\begin{array}{l}4.0 \\
4 \cdot 0 \\
4 \cdot 0\end{array}$ & $\begin{array}{l}24 \mathrm{~h} \\
72 \mathrm{~h} \\
7 \text { days }\end{array}$ & $\begin{array}{l}\text { ND } \\
\text { ND } \\
\text { ND } \\
\text { ND } \\
\text { ND } \\
\text { ND }\end{array}$ & $\begin{array}{l}\text { NA } \\
\text { NA } \\
\text { NA } \\
\text { NA } \\
\text { NA } \\
\text { NA }\end{array}$ & $\begin{array}{l}0.47 \\
0.47 \\
0.066 \\
0.137 \\
0.005 \\
0.018\end{array}$ & $\begin{array}{c}11 \cdot 8 \\
11.8 \\
1.6 \\
3.4 \\
0.12 \\
0.4\end{array}$ \\
\hline
\end{tabular}

ND $=$ Not detected

NA $=$ Not assayed 

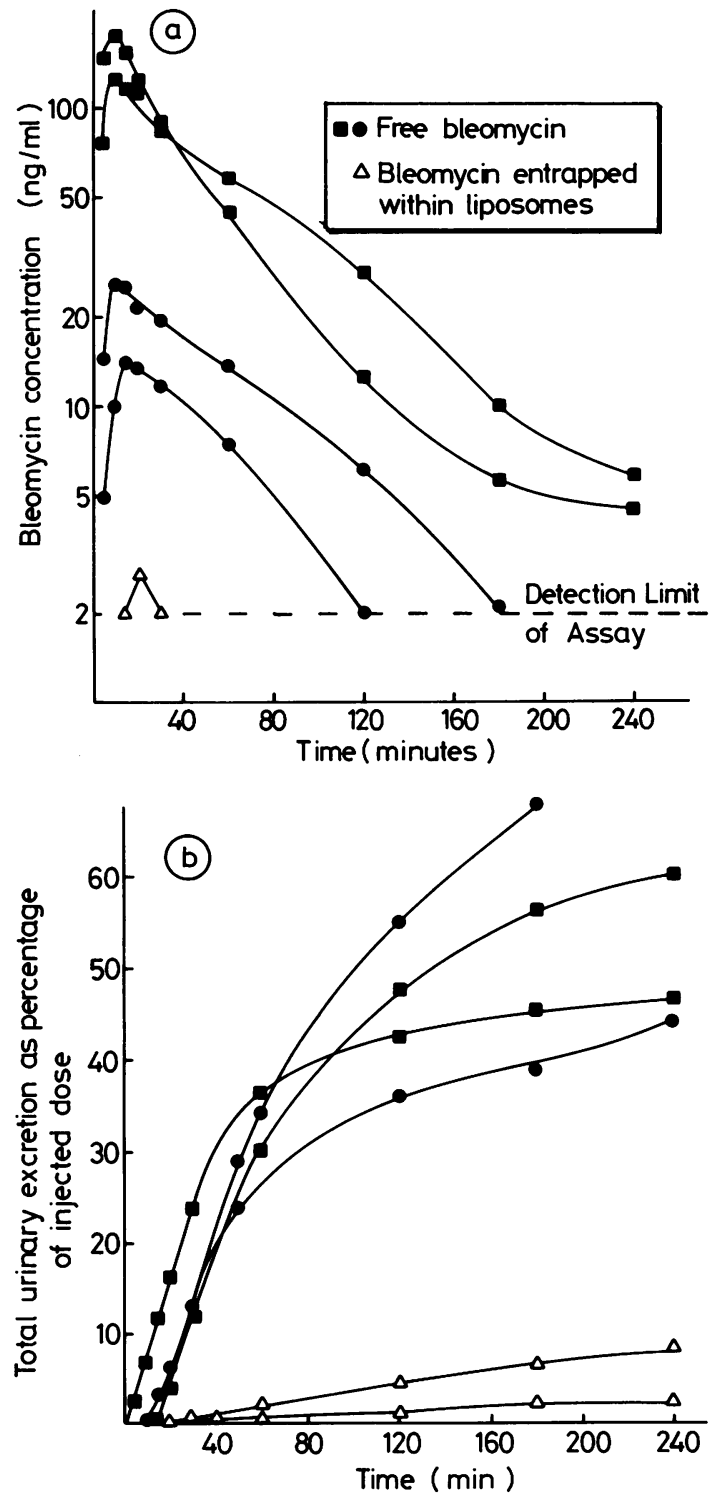

Fig. 1 (a) Serum bleomycin levels following intracerebral injection of free bleomycin and bleomycin entrapped within liposomes in the rat. $20 \mu \mathrm{g} B$ BEOMYCIN, $5 \mu \mathrm{g}$ BLEOMYCIN, $\triangle 7 \mu \mathrm{g}$ BLEOMYCIN. (b) Urinary clearance of bleomycin following intracerebral injection of free bleomycin and bleomycin entrapped within liposomes in the rat. $20 \mu \mathrm{g} B L E O M Y C I N, \bigcirc 5 \mu \mathrm{B}$ BLEOMYCIN, $\triangle 7 \mu \mathrm{B} B \mathrm{~B} O M Y C I N$.

blood were at or below the detection limit of this method and very low levels of drug were recorded in the urine. It is very unlikely that these marked differences could be accounted for by either inter- animal variation or assay imprecision (interassay coefficient of variation of $3.5 \%$ at a level of $50 \mathrm{ng} / 1$ and an intraassay CV of $7.5 \%$ at a level of $50 \mathrm{ng} / \mathrm{l}$ ).

Measurement of the amount of bleomycin in the brain demonstrated that most of the bleomycin remained localised to the injected hemisphere at 4 hours, after free and liposome entrapped bleomycin had been injected and also at 1, 3 and 7 days, in the liposome experiments where sufficient drug remained to be estimated. At 4 hours after injection twice the amount of bleomycin could be detected in the brain of rats given bleomycin entrapped within liposomes as compared to those given the same amount of the free drug. At 1, 3 and 7 days, 12, 2.5 and $0.25 \%$ of the total dose of bleomycin given entrapped within liposomes remained within the brain whereas minimal levels could be detected in the animals given the free drug.

Under the conditions of the experiment no tissue levels (lung, spleen, liver, kidney, small intestine, bladder and muscle) of bleomycin other than those in brain referred to above could be detected after 4 hours, 1, 3 and 7 days of intracerebral injection of free and liposome-entrapped bleomycin.

\section{Discussion}

Liposomes have recently been extensively studied as possible vehicles for delivering enzymes, antibodies and drugs to target organs in animal and human experiments. ${ }^{9}$ Thay are compsed of spheres of phospholipid and certain other lipids and consist of multilamellar or unilamellar structures of varying size alternating with aqueous compartments. The possibility that liposomes of defined constitution could be safely injected intracerebrally in the mouse was demonstrated by Adam et al. ${ }^{10}$ This suggested that liposomes could be used as carriers of therapeutic agents in the central nervous system. Certain types of liposome however cause extensive tissue damage, epilepsy and death (phosphatidyl choline, cholesterol and diacetyl phosphate; phosphatidyl choline, cholesterol and stearylamine), whereas others are well tolerated (phosphatidyl choline, cholesterol and phosphatidic acid; dipalmitoyl phosphatidyl choline). Our studies have confirmed that liposomes containing dipalmitoyl phosphatidyl choline, cholesterol and phosphatidic acid can safely be given intracerebrally into the rat with no added cerebral trauma or reaction beyond that of the injection, or alternation in behaviour. The potential advantage in using liposomes containing the above lipids as used in these experiments is that they are semi-synthetic and thus of defined constitution as compared to lecithin containing liposomes used in the earlier mouse experiments which is derived from egg white. 
Bleomycin has been extensively studied as a chemotherapeutic agent particularly in the treatment of human ectodermally derived tumours. "It is an antibiotic isolated from Streptomyces verticullis particularly effective against certain types of cancer such as those of the skin, head and neck and especially squamous cell carcinoma. It is believed to produce fewer side effects than conventional chemotherapeutic agents with the exception of cutaneous and pulmonary complications. Its mode of action is to produce scission of DNA strands and thus to hinder cell division. ${ }^{12}$

We were unable to detect bleomycin other than in the brain by radioimmunoassay after intracerebral injection of the free or liposome entrapped drug. This is at variance with previous work in which radio-labelled bleomycin has been given systemically and tissue levels of radioactivity measured ${ }^{13}$ but is in agreement with similar studies in which a microbiological assay has been used to measure active drug. ${ }^{14}$ This discrepancy has been shown to be due to the presence of a tissue hydrolase present in all tissues other than ectodermally derived. ${ }^{15}$ Thus when radioactive bleomycin is administered both the free drug and its metabolites will be measured whereas with the microbiological and radioimmunoassay methods only pharmacologically or antigenically active drug respectively will be measured. This presumably explains the peculiar effectiveness of this drug against cutaneous tumours and encourages the belief that if sufficient drug could be delivered to gliomas and a therapeutic concentration maintained it might be very effective against that type of tumour.

These studies demonstrate that bleomycin injected intracerebrally either as the free drug or entrapped within liposomes is of low toxicity to normal rat cerebral cortex even at quite high concentrations. When bleomycin is entrapped within liposomes and injected intracerebrally it has been shown in these experiments to act as a depot preparation with reduced clearance from the brain and without detectable blood levels and much reduced urine levels as compared to those obtained after injection of the free drug. Thus these results encourage the belief that liposomes containing chemotherapeutic agents could be used in the treatment of human gliomas with the advantage that high levels of bleomycin could be given into the tumour to enable the sustained release of drug to occur over several days with little danger of systemic side effects.

We thank St George's Hospital Medical Research
Committee and the South West Thames Locally Organised Research Scheme for financial support which enabled these studies to be undertaken.

\section{References}

${ }^{1}$ Levin VA, Edwards MS. Chemotherapy of Primary Malignant Gliomas in brain tumours: Scientific Basis, Clinical Investigations and Current therapy. Thomas DGT, Graham DI, eds. London; Butterworths, 1980.

${ }^{2}$ Takeuchi K. Effect of bleomycin on brain tumours. Gann Monogr Cancer Res 1976;19:117-32.

${ }^{3}$ Hayakawa T, Ushio Y, Mogami H, Horibata K. The uptake, distribution and anti-tumour activity of bleomycin in gliomas in the mouse. Eur $J$ Cancer 1974; 10: $137-42$.

${ }^{4}$ Hayakawa T, Ushio $Y$, Morimoto K, Hasegawa $H$, Mogami H, Horibata K. Uptake of bleomycin by human brain tumours. J Neurol Neurosurg Psychiatry 1976; 39:341-9.

5 Vats TS, Morantz RA, Wood GW, Tilzer S. Study of effectiveness of bleomycin in rat brain tumor model intravenously and intracerebrally. Int $J$ Radiation Oncology Biol Phys 1979;5:1527-9.

${ }^{6}$ Firth GB, Oliver AS, McKeran RO. Studies on the use of antimitotic drugs entrapped with liposomes and of their action on a human glioma cell line. (In press).

${ }^{7}$ Salacinski P, Hope J, Mclean C, et al. A new simple method which allows theoretical incorporation of radio-iodine into proteins and peptides without damage. J Endocrinol 1979;81:131p.

${ }^{8}$ Szoka F, Papahadjopaulos D. Procedure for the preparation of liposomes with large internal acqueous space and high capture by reverse-phase evaporation. Proc Nat Acad Sci 1978;75:4194-8.

${ }^{9}$ Gregordiadis G, Allison AC. Liposomes in Biological Systems. Chichester; John Wiley and Sons, 1980.

${ }^{10}$ Adams DH, Joyce G, Richardson VJ, Ryman BE, Wisniewski HN. Liposome toxicity in the mouse central nervous system. J Neurol Sci 1977;31:173-9.

"Umezawa H, Meada K, Takeuchi T, Okami Y. New antibiotics, bleomycin A and B. J Antibiot Ser $A$ 1966; 19:200-9.

12 Yamazaki Z, Muller WEG, Zahn RK. Action of bleomycin on programmed synthesis. Influence on enzymatic DNA, RNA and protein synthesis. Biochem Biophys Acta 1973;308:412-21.

${ }^{13}$ Amezawa H, Ishizuka M, Hori S, Chimura H, Takeuchi $\mathrm{T}$, Komai $\mathrm{T}$. The distribution of $3 \mathrm{H}$-bleomycin in mouse tissue. J Antibiot 1968;21:638-44.

${ }^{14}$ Pittillo RF, Woolley C, Rice LS. Bleomycin, an Anti tumour antibiotic - Improved Microbiological Assay and Tissue Distribution Studies in Normal Mice. Appl Microbiol 1971;22:564-6.

15 Umezawa H. Bleomycin: Current Status and New Developments, Carter SK and Crooke ST, eds. New York. Academic Press. 1978. 